\title{
Determinants of the capital structure of small and medium enterprises: Empirical evidence in the public works and hydraulics sector from Algeria
}

\author{
Factores determinantes de la estructura de capital de las pequeñas y \\ medianas empresas: Evidencia empírica en el sector de obras públicas e \\ hidráulicas de Argelia

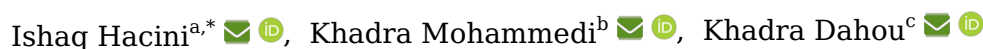 \\ $a, b, c)$ University of Mascara (Algeria) \\ * Primary Contact: i.hacini@univ-mascara.dz (Ishaq Hacini)
}

\begin{abstract}
This study aims to identify the determinants of the capital structure of SMEs in Algeria during the period 2010-2018. Where a sample consists of 20 SMEs from the Public Works and Hydraulics sector. The study used financial leverage as the dependent variable and assets structure, profitability, liquidity, and size as independent variables. The study used Panel Data methods for testing the hypothesis. The results show that profitability, liquidity, and assets structure are negatively related to financial leverage, while size does not affect the financial leverage. The results indicate that SMEs in Algeria rely on their internal resources to finance their activities.

Keywords: capital structure; small and medium enterprises; financial leverage; Algeria

JEL Classification: C33; D22; G32

Resumen

Este estudio tiene como objetivo identificar los factores determinantes de la estructura de capital de las PYMES en Argelia para el período 2010-2018 tomando una muestra formada por 20 pymes del sector de obras públicas e hidráulicas. El estudio utilizó el apalancamiento financiero como variable dependiente y la estructura de activos, la rentabilidad, la liquidez y el tamaño como variables independientes. El estudio utilizó métodos de datos de panel para probar las hipótesis. Los resultados muestran que la rentabilidad, la liquidez y la estructura de los activos están relacionadas negativamente con el apalancamiento financiero, mientras que el tamaño no afecta al apalancamiento financiero. Los resultados indican que las PYME de Argelia dependen de sus recursos internos para financiar sus actividades.
\end{abstract}

Palabras clave: estructura del capital; pequeña y mediana empresa; apalancamiento financiero; Argelia Clasificación JEL: C33; D22; G32 


\section{Introduction}

SMEs are very important in any economy; they are a backbone of any economy, as well as an alternative motor for economic development. SMEs have a crucial role in achieving the economic goals, in which they contribute to the diversification of the economy, reduce unemployment, enhance the country's production, and boost exportation. SMEs have contributed to the creation of nine jobs from every ten jobs in the world (Bruhn et al., 2017). However, SMEs around the world are suffering from many constraints that prevent their expansion and growth. The literature has revealed that lack of finance is a crucial obstacle that faces SMEs in any region in the world (Myers, 1984; Seker \& Correa, 2017), because they need financial resources that fit their characteristics to fill the financing gap (Beck, 2007). Ayadi and Gadi (2013) mentioned that the characteristics of SMEs (e.g. small size, weak capital structure, limited markets) increase their default risk, which makes them undesirable borrowers for the financial institutions. Kuntchev et al. (2013) revealed that, in developing countries, small firms have more constraints to get credit compared to large firms, which means that debt is not the principal source to finance their activities. Consequently, SMEs use internal resources such as owners' funds, profit, and loans from friends. World Bank (2013) has reported that many SMEs around the world have large needs for finance, but they do not apply for credit. This fact has been confirmed in 20 percent of SMEs in high-income countries, 28 percent in middle-income countries, and 44 percent in low-income countries. In the literature, there is no inclusive rule about the capital structure of SMEs. However, some studies have suggested that the capital structure is mainly determined by the firm characteristics rather than the industry factors (Balakrishnan \& Fox, 1993; Jordan et al., 1998).

The country characteristics determine the firms' specific factors that affect the capital structure. Moreover, the country characteristics control the magnitude of the effect of the capital structure determinants. However, the theories that explain the capital structure of firms in developed countries cannot necessarily identify the optimal capital structure of firms in developing countries such as Algeria. Therefore, it is interesting to examine the factors that influence the capital structure to pick out the appropriate capital structure of SMEs in developing countries.

Indeed, many factors may create financing constraints in developing countries. Information asymmetry is higher in developing countries than the developed countries, which increases the perceived risks of firms (Eldomiaty, 2008). In addition, financial markets in developing countries are less efficient, which prevents the firms to choose the optimal capital structure. Thus, Demirguc-Kunt and Maksimovic (1996) found a negative relationship between the stock market's development and the firms' financial leverage, and a positive relationship between the banking sector's size and the indebtedness. Many studies have revealed that the institutional environment, such as legal system, creditors' protection, financial system, fiscal system, economic development, is among the main factors that create the differences in capital structure between the developed and developing countries (Delcoure, 2007; Demirgüç-Kunt \& Maksimovic, 1999; González \& González, 2008; López-Iturriaga \& Rodríguez-Sanz, 2008).

In this context, Cornelli et al. (1998) revealed that the level of a firm's financial leverage in developing countries is lower than the developed countries. Moreover, de Jong et al. (2008) have found that in countries with strong legal environments and good economic conditions, their firms have a high level of indebtedness.

In the nineties, Algeria has adopted extensive programs of reforms in all the country's fields. In the economy, it decided to abandon the socialist economy and shift towards the market-oriented system (Hacini \& Dahou, 2013). Accordingly, the promotion of SMEs was among the policies that the Algerian authorities adopted to prosper the economy. Although, the importance of SMEs in the economy of any country, SMEs in Algeria are suffering from many obstacles such as; finance, real estate, legislation, etc. (EL Hadj, 2002). Moreover, many studies have suggested that the availability of the appropriate financial resources is one of the main obstacles facing SMEs in developing countries such as Algeria, among others, Amir (2015, 2016), and Radjal and Barrak (2017).

As the financing decision and the capital structure are the underpinnings of SME growth, this study aims to identify the main factors that determine the capital structure of SMEs in Algeria. The study focused on the main SME's characteristics cited in the literature and factors for which sufficient data are available during the period of the study. As a result, the study used firm size, profitability, liquidity, and assets structure as main factors that may determine the capital structure of SMEs in Algeria, in line with the following studies Hall et al. (2004), Sogorb-Mira (2005), Abor and Biekpe (2009), and Delikanlı and Kılıç (2021).

The study selected 20 SMEs from the Public Work and Hydraulic sector. The sample was selected based on the availability of data during the period from 2010 to 2018. Data were obtained from the financial statements, which were collected from the database of the National Center for Commercial Register (CNRC) of Algeria. CNRC's database contains the financial statements of all the firms operating in Algeria; in addition, it classifies the firms according to their sector. Moreover, the study selected the Public Works and Hydraulics sector because it is a manufacturing sector, in which firms rely more on external finance compared to the service firms. On the other hand, manufacturing firms have low financial constraints compared to service firms 
(Cressy \& Olofsson, 1997). This fact may be explained as the manufacturing firms have high tangible assets, which helps them reduce their perceived risk when they ask for credits. Hence, manufacturing firms display low financial constraints compared to service firms.

The study contributes to the literature on the topic of the capital structure of SMEs, which is still ambiguous. First, this topic has been vastly investigated for large firms (Rajan \& Zingales, 1995; Chakraborty, 2010; Handoo \& Sharma, 2014), but the results of these studies cannot apply to SMEs due to the characteristics of each type. Second, the factors that determine the capital structure of SMEs are not well determined, especially in developing countries, because most researches have been conducted in developed countries. Country features, regarding information asymmetry and financial markets development, among other aspects, determine both the firm's specific factors and the magnitude of their effect on the capital structure. Consequently, this study contributes to prior literature analyzing the particular factors that influence the capital structure of SMEs in a developing country, namely, Algeria, so the findings of this study might be useful for the other developing countries. Indeed, the paucity of accurate data and databases of SMEs in developing countries has restrained the research on this topic. There is a great scarcity of research about SMEs in Algeria because SME is a nascent type of business in this country. Further, the unavailability of detailed data in Algeria has impeded the understanding of SME financing decisions so far. Therefore, and third, this study aims to be a reference to investigate the capital structure's determinants of SMEs operating in countries with transitional economies, in which they are moving from a socialist economy towards a marketoriented system.

\section{Literature review and hypotheses development}

\subsection{Characteristics of SMEs in Algeria}

The World Bank defines SMEs based on three criteria: number of workers, total assets, and annual sales, as Table 1 shows (World Bank, 2019).

Table 1. World Bank criteria

\begin{tabular}{|l|c|c|c|}
\hline \multicolumn{2}{|c|}{ Workers } & $\begin{array}{c}\text { Total assets } \\
\text { (U.S dollars) }\end{array}$ & $\begin{array}{c}\text { Annual sales } \\
\text { (U.S dollars) }\end{array}$ \\
\hline Microenterprise & $<10$ & $<1,000$ & $<1,000$ \\
\hline Small enterprises & 10 to 49 & $<3,000,000$ & $<3,000,000$ \\
\hline Medium institutions & 5 to 300 & $<15,000,000$ & $<15,000,000$ \\
\hline Source: World Bank (2019) & &
\end{tabular}

In Algeria, Article 05 of Law 17-02 defined an SME as: "enterprise of production of goods and/or services whatever its legal form, which employs from 01 to 250 people, and its sales do not exceed four billion Algerian dinar, or its total annual revenue does not exceed one billion Algerian dinar"1.

Table 2. Algerian classification of SMEs

\begin{tabular}{|l|c|c|c|}
\hline \multicolumn{1}{|c|}{ Classification } & Workers & Total & Percentage \\
\hline Microenterprise & $<10$ & $1,136,787$ & 97 \\
\hline Small enterprise & 10 to 49 & 30,471 & 2.6 \\
\hline Medium enterprise & 50 to 249 & 4,688 & 0.4 \\
\hline Total institutions & $1,136,787$ & 100 \\
\hline
\end{tabular}

SMEs in Algeria are classified based on many criteria; number of workers and legal nature. Table 2 shows the classification of SMEs based on the number of workers.

Figure 1. The number of SMEs during the period 2010-2018

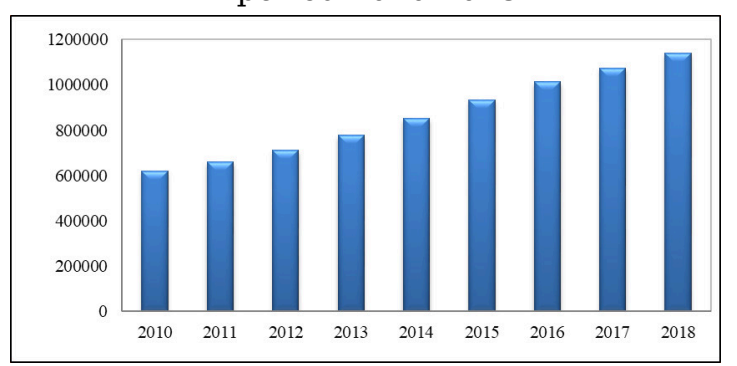

Source: Ministry of Industry and Mines (2019) 
At the end of the first quarter of 2019, the total number of SMEs reached 1,171,945, classified as follows, $97 \%$ are Microenterprise, $2.6 \%$ are small enterprises, and $0.40 \%$ are medium enterprises. Figure 1 shows that the number of small enterprises has increased gradually in Algeria from 2010 to 2018.

SMEs contribute significantly to creating wealth around the world. SMEs represent 90\% of companies globally; they contribute to $50 \%$ of employment around the world and contribute up to $40 \%$ of national income in the emerging countries (World Bank, 2019). In developed countries, SMEs contribute to 60 to $70 \%$ of employment and 55\% of GDP (Arnold, 2018). Figure 2 shows the contribution of SMEs to GDP in Algeria. It is clear that the private sector has the biggest share in the creation of GDP.

Figure 2. The contribution of SMEs to GDP

(2010-2018)

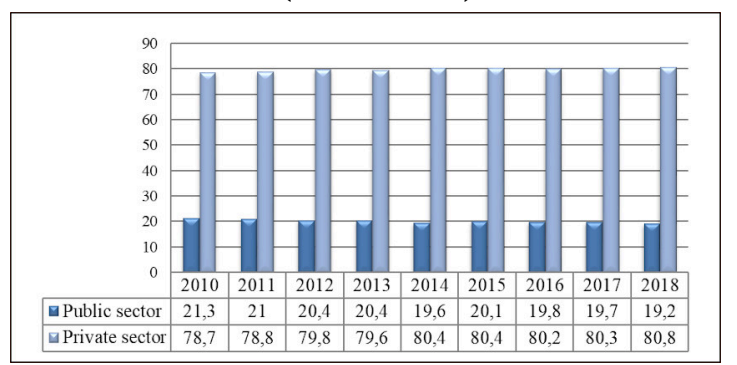

Source: Berrah $(2015,2019)$

Private sector enterprises contribute significantly to the creation of jobs, more than the contribution of the public sector, see Figure 3.

Figure 3. Contribution of SMEs for jobs (2010-2018)

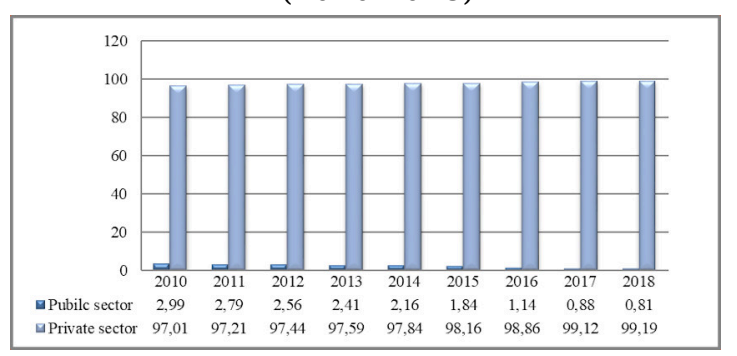

Source: Ministry of Industry and Mines (2019)

In Algeria, SMEs are still in the nascent stage, wherein in 2018, Algeria has registered a ratio of 25 SMEs for every 1,000 habitants, well behind the world average with 45 SMEs for every 1,000 habitants. The majority of SMEs in Algeria are small enterprises with a share of $97.1 \%$, while the medium enterprises represent $0.31 \%$. The dominance of small enterprises over the other types is an essential feature in many emerging countries. Indeed, access to finance is a big problem for all firms in Algeria. In 2018, world banks in "doing business report" ranked Algeria for credit access in the position 177 from 199 countries surveyed. Accordingly, SMEs in Algeria face many difficulties to get finance due to the weakness of the financial market and underdevelopment of the banking sector.

To develop SMEs, the government in Algeria has adopted many policies and procedures, among others, it created three organisms; ANSEJ (National Agency for Youth Employment Support) was created in 1996, for the mission of supporting the creation of the micro-enterprises for the young people. ANGEM (National Agency for Management of Microcredit) was created in 2004, to grant loans with a free interest rate for small businesses. CNAC (National unemployment Insurance Fund) was created in 1994. In 2004, it has been assigned to support the creation of a new project for young unemployed entrepreneurs. Moreover, in 2011, the government has adopted a national program to promote SMEs and achieve the objective of the 2 million SMEs in 2025.

\subsection{Capital structure}

The capital structure is a mixture of a company's debt (long-term and short-term), common equity, and preferred equity (Arulvel \& Ajanthan, 2013). Brigham and Houston (2009) defined capital structure as, "mix of debt, preferred stock, and common equity the firm wants to have". Also known as the permanent financing represented by long-term debt, preferred stock, and shareholder equity, excluding all types of short-term credit (Khanna et al., 2015). 
The starting point of all studies on capital structure is launched from the theory of irrelevance of the Modigliani and Miller, which was first published in 1958. The theory suggested that the firm's value is not affected by debt and equity mix, but the firm's value is determined by the investment policy (Ain et al., 2011). Indeed, three main theories that explain the capital structure. Trade-off theory states that a firm trades off the tax benefits of debt financing against the risk of potential bankruptcy, it also determines the optimal structure as a result of balancing between costs and benefits of issuing debt and capital (Brigham \& Houston, 2009). For this approach, leverage is considered advantageous (under certain conditions), and owner-managers prefer using debt even if the availability of internal funds. This theory assumes that the optimal capital structure is the result of the balance between the benefits of leverage (mainly tax savings) and the capital costs. Thus, if companies become indebted, the tax savings are expected to be greater, as well as the costs arising from the risk of default. This theory recommended that firms should avoid the extreme use of leverage and rationalize the usage of debt (Martinez et al., 2019). Pecking order theory does not consider the optimal capital structure. It suggested that firms prefer internal financing (retained earnings, or liquidity surplus) to external financing. If internal funds were not sufficient to finance the investment opportunities, possibly the firms get external financing firstly. They should evaluate all the external sources to select the appropriate source with low financing costs. The theory suggested that financing alternatives are arranged as follows; internal funds, then low-risk debt, and finally equity. Myers and Majluf (1984) argued that stock price falls when managers issue new shares instead of non-risky debt. Therefore, they suggested that managers use internal funds first, then risky debt, and lastly equity. If firms do not invest, they will retain the profits to avoid external funding (Luigi \& Sorin, 2009). Market Timing Theory stated that the financing decision depends on the market situation. Debt is favorable when Treasury bill rates are low, which is known as debt market timing, and the equity is favorable when the market to book ratio is high, which is known as equity market timing. If both situations are not favorable, firms should defer the operation of capital raising (Frank \& Goyal, 2009). This theory focused on the managers' ability to time the market and select the appropriate time to raise the firm capital cheaply (Khanna et al., 2015).

\subsection{Firm's characteristics}

Many studies have revealed that the firm's characteristics are the main factors that determine the financing decision of SMEs (e.g. Balakrishnan \& Fox, 1993; Jordan et al. ,1998; Hall et al., 2004; Sogorb-Mira, 2005; Abor \& Biekpe, 2009; Delikanlı \& Kılıç, 2021). Hence, this study chose size, profitability, liquidity, and assets structure as the main characteristics that may determine the capital structure of SMEs in Algeria.

Firm size is an important factor that determines the performance of any firm. However, it was used in most studies that investigate the capital structure of SMEs. The evidence revealed that there is a positive relationship between SME's size and financial leverage, which means that small firms use less debt compared to large firms (Barton et al., 1989; Sogorb-Mira, 2005; M'ng et al., 2017; Jędrzejczak-Gas, 2018). Otherwise, some studies have found a negative relationship between the firm's size and the financial leverage, among others Nasimi (2018) and Rao et al. (2019). Indeed, small firms consider deb as a costly resource due to the information asymmetries costs and credit service costs. Thus, small firms avoid debt and use it only in urgent situations. Moreover, the evidence revealed that transaction costs are a function of the operation's scale, and the transaction costs are negatively correlated to the firm's size. It is expected that small size firms bear high transaction costs; consequently, they will borrow less (Hamilton \& Fox, 1998). On the other hand, large firms have high access to credit because they have large assets and they can generate stable profits. These characteristics help them to use debt to finance their activities without deteriorating the firm's creditworthiness. Based on these arguments, the following hypothesis is formulated:

\section{H1: firm's size has a positive effect on SMEs' financial leverage.}

Profitability is another factor that may affect the capital structure of SMEs. Undoubtedly, SMEs suffer from a high level of financial constraint. Thus, they tend to use their profits to finance their activities. Likewise, pecking order theory suggested that firms prefer internal capital and avoid debt. Therefore, SMEs with high profitability tend to use less debt because they possess enough internal financing (Forte et al., 2013; Napompech, 2013; Saarani \& Shahadan, 2013; M’ng et al., 2017; Al-Smadi, 2019; Rao et al., 2019). Some studies have suggested a positive relationship between profitability and the firm financial leverage (Mota \& Moreira, 2017; Jędrzejczak-Gas, 2018). Based on the previous reasoning, we put forward the following hypothesis:

\section{H2: profitability has a negative effect on SMEs' financial leverage.}

Liquidity is an important determinant of the capital structure of SMEs. However, many studies have found a negative relationship between SME liquidity and financial leverage (e.g. Korkmaz et al., 2007; Guler, 2010; Mateev et al., 2013; Saarani \& Shahadan, 2013; Serrasqueiro et al., 2016; Jędrzejczak-Gas, 2018). On the other hand, some studies found a positive relationship between the firm's liquidity and financial leverage (Ghasemi \& Hisyam Ab Razak, 2016; Hongli et al., 2019). The negative relationship between liquidity and financial leverage may be explained by the fact that SMEs that generate more liquidity can meet their short- 
term obligations and do not need borrowing. Based on these assertions, we set out the following hypothesis:

\section{H3: liquidity has a negative effect on SMEs' financial leverage.}

Assets structure represents the share of fixed assets from the total assets. Firms that hold more fixed assets such as; buildings, land, etc., can use them as guarantees and collateral to get more loans. Bradley et al. (1984) suggested that firms with large assets are secured borrowers; consequently, they can get loans at low interest rates. Indeed, the inability of SMEs to meet the collateral requirement is the main obstacle that faces them to gain access to debt. Thus, fixed assets improve the firm's ability to increase the share of debt in its capital structure. This evidence is well documented by many studies, among others, Nguyen and Ramachandran (2006), Bayrakdaroglu et al. (2013), M'ng et al. (2017), and Mota and Moreira (2017). Accordingly, it is expected that SME's assets structure has a positive effect on its financial leverage. In contrast, other studies found a negative effect of SME's assets structure on its financial leverage (e.g. Saarani \& Shahadan, 2013; San Martín \& Saona, 2017; Jędrzejczak-Gas, 2018; Al-Smadi, 2019). Based on the abovementioned discussion, we expect a positive relationship between SME's assets structure and the financial leverage. Thus, the following hypothesis is formulated:

H4: Assets structure has a positive effect on SMEs' financial leverage.

\section{Research Methodology}

This section presents the sample of the study, data, and method of collection. It also presents the variables and their measurement. Finally, it exhibits the model of the study.

\subsection{Data}

The study focused on SMEs in the Public Work and Hydraulic sector. This sector is appropriate for SMEs in Algeria, thus, it contains many SMEs because it offers many opportunities for small firms, in which the government has launched many projects in this sector in the context of the economic development of the country. The study selected a sample of 20 SMEs operating in the Public Work and Hydraulic sector. The selection of the sample is determined by the availability of data during the period of the study from 2010 to 2018. Data were collected from the financial statements of SMEs, which are published by CNRC. CNRC publishes all information about the firms operating in Algeria; in addition, it classifies them according to their activities into sectors. Accordingly, the study followed CNRC classification to select the sample of the study. CNRC counts 222 firms in the Public Work and Hydraulic sector, among them 201 firms are SMEs. Unfortunately, only 20 SMEs have the required data during the period of the study.

\subsection{Variables and research model}

The study used SME financial leverage as the dependent variable, where, size, profitability, liquidity, and assets structure are the independent variables. All the variables were measured based on their book value (Myers, 1984). Financial leverage was used as a proxy for SME capital structure. In literature, there is almost unanimity to use the financial leverage as a measure of capital structure and financing decision (e.g. Cassar \& Holmes, 2003; Hall et al., 2004; Heyman et al., 2008). In contrast, few studies have used equity as a proxy to measure financial decisions. Therefore, the study used total debt to total assets ratio to measure SME's financial leverage, in line with the studies of Habib et al. (2016), Rao et al. (2019), and Delikanlı and Kılıç (2021). The firm's size was measured as the logarithms of total assets following Sogorb-Mira (2005), Abor and Biekpe (2009), Sahin (2018), and Rao et al. (2019). Profitability was measured as the ratio of profit before tax to total assets following Sogorb-Mira (2005), Heyman et al. (2008), Abor and Biekpe (2009), and Rao et al. (2019). Liquidity was measured as the ratio of current assets to current liabilities, according to Hongli et al. (2019) and Rao et al. (2019). Assets structure represents the share of fixed assets in the total assets, thus it was measured as the ratio of fixed assets to total assets, according to Sogorb-Mira (2005), Abor and Biekpe (2009), Jędrzejczak-Gas (2018), and Delikanlı and Kılıç (2021). Table 3 exhibits the descriptive statistic of the study's variables for the sample of the study. Consequently, the model of the study can be formulated as:

$$
\text { leverage }_{i t}=\beta_{0}+\beta_{1} \cdot \log (\text { assets })_{i t}+\beta_{2} \cdot \text { profitability }_{i t}+\beta_{3} \cdot \text { liquidity }_{i t}+\beta_{4} \cdot \text { structure }_{i t}+\varepsilon_{i t}(1)
$$

Where $i$ represents the number of firms from the sample (1 to 20). $t$ represents time according to the period of the study (2010 to 2018). Leverage is the financial leverage, log assets is the firm's size, profitability is the firm's profitability, liquidity is the firm's liquidity, structure is the firm's assets structure, and $\varepsilon$ is the stochastic error term.

For testing the hypothesis, the study used the panel data method. Accordingly, the model of the study was estimated using three methods; pooled Ordinary Least Square (OLS), Fixed Effects (FE), and Random Effects (RE). Furthermore, the study applied the Breusch and Pagan Lagrangian multiplier test (LM) and Hausman 
test to select the appropriate method from the three methods. Finally, the study used the Huber/White robust method to control the heteroscedasticity problem.

Table 3. Descriptive statistics

\begin{tabular}{|l|c|c|c|c|c|}
\hline Variable & Mean & Std. Dev & Min & Max & Obs \\
\hline Leverage & 0.7688 & 0.2215 & 0.1683 & 13.434 & $\mathrm{~N}=180$ \\
\hline Profitability & 0.0301 & 0.0707 & 0.2660 & 0.2476 & $\mathrm{~N}=180$ \\
\hline Liquidity & 0.9488 & 0.4607 & 0.0394 & 27.185 & $\mathrm{~N}=180$ \\
\hline Structure & 0.3381 & 0.2285 & 0.0006 & 0.9627 & $\mathrm{~N}=180$ \\
\hline Log assets & 188.891 & 11.590 & 157.339 & 21.887 & $\mathrm{~N}=180$ \\
\hline
\end{tabular}

Note: Structure (Assets structure), log assets (Size), profitability, liquidity (Log Liquidity)

\section{Results and Discussion}

Before estimating the model of the study, the stationarity of the variables was tested. The study used Pesaran's CADF test for testing the stationarity according to the following hypothesis: H0: The series is non-stationary at the level; H1: The Series is stationary at the level.

Table 4. Stationarity test

\begin{tabular}{|l|c|c|}
\hline \multicolumn{1}{|c|}{ Variable } & statistic & Probability \\
\hline Leverage & -2.712 & 0.003 \\
\hline Profitability & -4.169 & 0.000 \\
\hline Liquidity & -2.871 & 0.002 \\
\hline Structure & -2.066 & 0.019 \\
\hline Log assets & -1.596 & 0.055 \\
\hline
\end{tabular}

Note: Structure (Assets structure), log assets (Size), profitability, liquidity (Log Liquidity)

Table 4 presents the results of the stationarity test, which indicates that the probabilities of the test for all the variables are less than 0.005, except the size (Log assets), which is less than 0.1. This means that the null hypothesis of non-stationarity is rejected and all variables are stationary at the level.

Table 5. Results of OLS, FE, and RE

\begin{tabular}{|c|c|c|c|c|c|c|}
\hline & \multicolumn{2}{|c|}{ OLS } & \multicolumn{2}{|c|}{ FE } & \multicolumn{2}{|c|}{$\mathbf{R E}$} \\
\hline Leverage & Coef & $\operatorname{Pr}$ & Coef & $\operatorname{Pr}$ & Coef & $\operatorname{Pr}$ \\
\hline structure & -0.8192 & 0.000 & -0.7632 & 0.000 & -0.7683 & 0.000 \\
\hline Log assets & 0.0098 & 0.216 & -0.0209 & 0.162 & 0.0037 & 0.728 \\
\hline profitability & -0.3704 & 0.009 & -0.2603 & 0.049 & -0.2744 & 0.037 \\
\hline liquidity & -0.4315 & 0.000 & -0.3298 & 0.000 & -0.3815 & 0.000 \\
\hline constant & 0.7812 & 0.000 & 13.629 & 0.000 & 0.8866 & 0.000 \\
\hline $\mathrm{N}$ & \multicolumn{2}{|c|}{180} & \multicolumn{2}{|c|}{180} & \multicolumn{2}{|c|}{180} \\
\hline Firms & \multicolumn{2}{|c|}{20} & \multicolumn{2}{|c|}{20} & \multicolumn{2}{|c|}{20} \\
\hline $\mathrm{R}^{2}$ & \multicolumn{2}{|c|}{0.7233} & \multicolumn{2}{|c|}{0.6334} & \multicolumn{2}{|c|}{0.7186} \\
\hline F-Test & \multicolumn{2}{|c|}{$\begin{array}{l}114.37 \\
(0.000)\end{array}$} & \multicolumn{2}{|c|}{$\begin{array}{c}42.54 \\
(0.000)\end{array}$} & \multicolumn{2}{|c|}{ - } \\
\hline F-Test $\left(\right.$ all $\left.\mathrm{u}_{\mathrm{i}}=0\right)$ & \multicolumn{2}{|c|}{-} & \multicolumn{2}{|c|}{$\begin{array}{c}5.36 \\
(0.000)\end{array}$} & \multicolumn{2}{|c|}{ - } \\
\hline Wald chi ${ }^{2}$ & \multicolumn{2}{|c|}{-} & \multicolumn{2}{|c|}{-} & \multicolumn{2}{|c|}{$\begin{array}{l}254.88 \\
(0.000)\end{array}$} \\
\hline rho & \multicolumn{2}{|c|}{-} & \multicolumn{2}{|c|}{0.5597} & \multicolumn{2}{|c|}{0.2718} \\
\hline BP-LM Test & \multicolumn{2}{|c|}{ - } & \multicolumn{2}{|c|}{ - } & \multicolumn{2}{|c|}{$\begin{array}{c}\mathrm{Chi}^{2}(1)=34.10 \\
(0.000)\end{array}$} \\
\hline Hausman Test & \multicolumn{2}{|c|}{ - } & \multicolumn{2}{|c|}{ - } & \multicolumn{2}{|c|}{$\begin{array}{c}\mathrm{Chi}^{2}(4)=16.25 \\
(0.002)\end{array}$} \\
\hline
\end{tabular}

Note: Structure (Assets structure), log assets (Size), profitability, liquidity (Log Liquidity)

For estimating the model of the study, three methods were used; (OLS), (FE), and (RE). Table 5 summarizes the results of the three models.

Table 5 shows that the results of OLS indicate that profitability has a statistically significant negative effect $(-0.37)$ on financial leverage. Assets structure has a negative effect $(-0.81)$ and this effect is statistically 
significant at the $5 \%$ level. Liquidity also has a negative (-0.43) statistically significant effect on financial leverage. In contrast, size does not affect SMEs' financial leverage. The probability of $F$ test is less than 0.05 , which means that the model is significant and fits the data of the study. The value of $\mathrm{R}^{2}$ shows that the independent variables explain $72 \%$ of the variation of the financial leverage. However, the results of FE method show that FE is better than OLS because F-test shows that, the statistics of the test equals 5.36 and its probability is less than 0.05. In addition, F statistic equals 42.54 and its probability is less than 0.05 , which means that FE method is appropriate and fits well the data of the study. According to the results of FE; profitability, liquidity, and structure have negative effects and these effects are statistically significant at the 5 $\%$ level, while size has no effect.

Results of RE show that this method is appropriate because the probability of Wald chi ${ }^{2}$ is less than 0.05 . The result of BP-LM test indicates that the value of Prob $\left(\mathrm{Chi}^{2}\right)$ is 0.000 , which is less than $5 \%$; this suggests that $\mathrm{RE}$ is appropriate. This indicates that OLS is inadequate for estimating the model because of the heterogeneity between the firms of the sample. However, RE results confirm the results of FE, in which profitability, liquidity, and structure have negative effects and these effects are statistically significant at the 5\% level. The study used the Hausman test to compare between RE and FE methods. The result shows that Prob $\left(\mathrm{Chi}{ }^{2}\right)$ of the test is less than 0.05 (0.0027), which means that FE is the appropriate method for estimating the model of the study.

Table 6 presents the results of the FE model after controlling the problem of heteroscedasticity by applying Huber/White robust method.

Table 6. Results of Robust Fixed effects model

\begin{tabular}{|c|c|c|c|c|}
\hline & Coef & Std. Err. & $\mathbf{t}$ & Pr \\
\hline structure & -0.7632 & 0.1653 & -4.62 & 0.000 \\
\hline Log assets & -0.0209 & 0.0342 & -0.61 & 0.548 \\
\hline profitability & -0.2603 & 0.1448 & -1.80 & 0.088 \\
\hline liquidity & -0.3298 & 0.1156 & -2.85 & 0.010 \\
\hline constant & 13.629 & 0.6556 & 2.08 & 0.051 \\
\hline $\mathrm{R}^{2}$ & 0.6334 & & & \\
\hline Corr $\left(\mathrm{u}_{\mathrm{i}}, \mathrm{X}_{\mathrm{b}}\right)$ & 0.3830 & & & \\
\hline $\mathrm{F}(4,19)$ & 8.86 & & & \\
\hline Prob > F & 0.000 & & & \\
\hline rho & 0.5597 & & & \\
\hline $\mathrm{N}$ & 180 & & & \\
\hline
\end{tabular}

Results indicate that Assets structure and liquidity have negative significant effects on financial leverage at the $5 \%$ level, and profitability has a negative effect and it is statistically significant at the $10 \%$ level, while firm's size has no effect on the financial leverage.

The value of rho (0.5597) reveals that 55.97\% of the variance is explained due to the differences across the units of the study. The value of $\mathrm{R}^{2}(0.6334)$ indicates that $63 \%$ of the variance of the debt ratio is explained by the independent variables.

Results show that profitability has a negative effect on financial leverage, which means that high profitable SMEs borrow less. Thus, this result confirms the assumption of the pecking order theory that suggests that firms prefer using their internal resources and avoiding debts. On the other hand, profitable firms have sufficient internal capital to meet their financial needs, so they do not need to borrow and bear more costs. This result confirms the results of many previous studies, among others, Hall et al. (2004), Bayrakdaroglu et al. (2013), M'ng et al. (2017), and Rao et al. (2019). In addition, the results reveal that liquidity has a negative on SMEs' financial leverage, which means that SMEs realize high liquidity do not borrow and use their internal resources to meet their obligations. However, this evidence is in line with Serrasqueiro et al. (2016), Mota and Moreira (2017), and Jędrzejczak-Gas (2018). Finally, the results indicate that SME's assets structure has a negative effect on its financial leverage, this means that SMEs that have high fixed assets tend to borrow less and use their internal capital to finance their activities. On the contrary, other studies conducted in different countries revealed that SMEs use more debt when their fixed assets increase (Nguyen \& Ramachandran, 2006; Guler, 2010; Bayrakdaroglu et al., 2013; Forte et al., 2013; Balios et al., 2016). However, this evidence indicates that SMEs that invest more in fixed assets follow conservative policy toward debt for keeping their perceived risk at the lower level. Furthermore, this result may be explained by the fact that the owners of SMEs use their capital and funds collected from their families and friends to finance the investments of fixed assets. This result was confirmed by some studies (San Martín \& Saona, 2017; JędrzejczakGas, 2018; Sahin, 2018). 


\section{Conclusion}

This study examined the determinants of the capital structure of SMEs in Algeria during the period $2010-2018$. The study selected a sample of SMEs from the Public Works and Hydraulics sector. However, SMEs in Algeria are still in the nascent stage, in which they face many obstacles among other access to finance. Consequently, SMEs' financing decisions and capital structure are ambiguous. The results show that profitable SMEs have low financial leverage, which means that SMEs that realize high profitability tend to use their internal resources to finance their activities. Hence, this evidence confirms the assumptions of the pecking order theory in the Algerian context. Furthermore, results reveal that liquid SMEs have low financial leverage, which means that when SMEs hold high liquidity they do not need debts. Thus, SMEs should manage well their working capital to maintain a convenient level of liquidity, which gets them away from lenders that require high collateral for credit. Finally, the results show that SMEs in Algeria do not use debt to finance their fixed assets. In other words, in Algeria, SMEs tend to use the capital of the owners and funds collected from their families and friends to finance their investments and expand their activities. Moreover, SMEs with high fixed assets do not use debt in their capital. This fact demonstrates that SMEs face many constraints to gain access to debt.

The capital structure of SMEs in the Algerian Public Works and Hydraulics sector is mainly determined by profitability, liquidity, and assets structure. SMEs tend to use their internal resources to finance their activities and avoid debts. This evidence indicates that SMEs in Algeria have many constraints to debt access, even for the firms that have good creditworthiness. The results also confirm that firms in developing countries seem to target low financial leverage and they prefer equity to debt (Cornelli et al., 1998; Delcoure, 2007). On the other hand, the results also prove that in developing countries firms with high fixed assets tend to use less debt (Cornelli et al., 1998, Booth et al., 2001). Overall, the pecking order theory seems suitable for explaining the capital structure of SMEs in developing countries such as Algeria.

Accordingly, the study suggests that the public authorities in Algeria should provide a strong framework of regulations and laws to promote SMEs. In addition, they should provide more facilities and motivations for SMEs in the shape of tax exemption and low interest rates. Maimbo and Henriquez Gallegos (2014) revealed that around 76 countries adopt the policy of interest rate ceiling to support small borrowers and reduce the financing constraint. Furthermore, they should provide more facilities to help SMEs to access the financial markets and trade equity, this procedure helps SMEs to diversify their financial resources and reduce the financing gap.

In addition, there is a big problem of information asymmetry between banks and SMEs, which prevents banks to evaluate the creditworthiness of SMEs equitably. Thus, this problem obliges banks to ask for high collateral to secure their funds. To mitigate the effect of the credit's collateral, public authorities can create special institutions that provide the required guarantees for the banks in favor of SMEs. However, institutions with public ownership played important role in reducing the financing gap for SMEs in many developing countries (Beck et al., 2010). On the other hand, Banks and financial institutions can fill the financing gap by adopting a strategy that focuses on the SME's market. This strategy should take into consideration the characteristics of SMEs by offering products that fit SMEs' business model.

This study sought to contribute to the literature by understanding the characteristics of the capital structure of SMEs in the sector of Public Works and Hydraulics in Algeria. Nevertheless, many questions on this topic still need further research. In the future, this topic could be investigated across other sectors and in other developing countries to formulate a comprehensive rule concerning the factors that determine the capital structure of SMEs. Hence, more research could be conducted in the service sector, for instance, and make a comparison with the manufacturing sector or other industries to determine the effect of the industry characteristics on the capital structure of SMEs in developing countries.

\section{Footnotes}

${ }^{1}$ Law $\mathrm{N}^{\circ}(17-02), 2017, \mathrm{p} 04$. 


\section{References}

Abor, J., \& Biekpe, N. (2009). How do we explain the capital structure of SMEs in sub-Saharan Africa? Journal of Economic Studies, 36(1), 83-97. https://doi.org/10.1108/01443580910923812

Ain, Q., Jan, S. U., \& Rafiq, M. (2011). Effect of Macroeconomic Factors on Capital Structure Decisions of Firm: Evidence from a Developing Country. Business \& Economic Review, 3(1), 64-90. https://doi.org/10.22547/BER/3.1.5

Al-Smadi, M. O. (2019). A study of capital structure decisions by SMEs: Empirical evidence from Jordan. Academy of Accounting and Financial Studies Journal, 23(1). https://www.abacademies.org/articles/astudy-of-capital-structure-decisions-by-smes-empirical-evidence-from-jordan-7900.html

Amir, M. M. (2016). Signal theory As an entrance to interpretation the determinants of investment loan financing for SMEs under asymmetry of information. Journal of Economic and Management Sciences, 16, 104-131

Amir, M. M. (2015). The reality of bank financing for small and medium enterprises in Algeria. Journal of Industrial Economics, 12(3), 1-35. https://doi.org/10.12816/0017542

Arnold, C. (2018, June). The Foundation for Economies Worldwide Is Small Business. IFAC. https://www.ifac.org/knowledge-gateway/contributing-global-economy/discussion/foundation-economiesworldwide-small-business-0

Arulvel, K., \& Ajanthan, A. (2013). Capital structure and financial performance: A study of listed trading companies in Sri Lanka. ACADEMICIA: An International Multidisciplinary Research Journal, 3(6), 1. https://doi.org/10.5958/j.2249-7137.3.6.001

Ayadi, R., \& Gadi, S. (2013). Access by MSMEs to Finance in the Southern and Eastern Mediterranean: What Role for Credit Guarantee Schemes? MEDPRO Technical Report No. 35/April

Balakrishnan, S., \& Fox, I. (1993). Asset specificity, firm heterogeneity and capital structure. Strategic Management Journal, 14(1), 3-16. https://doi.org/10.1002/smj.4250140103

Balios, D., Daskalakis, N., Eriotis, N., \& Vasiliou, D. (2016). SMEs capital structure determinants during severe economic crisis: The case of Greece. Cogent Economics \& Finance, 4(1), 1145535. https://doi.org/10.1080/23322039.2016.1145535

Barton, S. L., Hill, N. C., \& Sundaram, S. (1989). An Empirical Test of Stakeholder Theory Predictions of Capital Structure. Financial Management, 18(1), 36. https://doi.org/10.2307/3665696

Bayrakdaroglu, A., Ege, I., \& Yazici, N. (2013). A Panel Data Analysis of Capital Structure Determinants: Empirical Results from Turkish Capital Market. International Journal of Economics and Finance, 5(4). https://doi.org/10.5539/ijef.v5n4p131

Beck, T. (2007). Financing Constraints of SMEs in Developing Countries : Evidence, Determinants and Solutions. Financing Innovation-Oriented Businesses to Promote Entrepreneurship

Beck, T., Klapper, L. F., \& Mendoza, J. C. (2010). The typology of partial credit guarantee funds around the world. Journal of Financial Stability, 6(1), 10-25. https://doi.org/10.1016/j.jfs.2008.12.003

Berrah, M. K. (2019). Les comptes économiques de 2015 à 2018. ( $N^{\circ}$ 861). Alger: la Direction Technique chargée de la comptabilité nationale

Berrah, M. K. (2015). Les comptes économiques de 2000 à 2014. (N 709). Alger: la Direction Technique chargée de la comptabilité nationale

Booth, L., Aivazian, V., Demirguc-Kunt, A., \& Maksimovic, V. (2001). Capital Structures in Developing Countries. The Journal of Finance, 56(1), 87-130. https://doi.org/10.1111/0022-1082.00320

Bradley, M., Jarrell, G. A., \& Kim, E. H. (1984). On the Existence of an Optimal Capital Structure: Theory and Evidence. The Journal of Finance, 39(3), 857. https://doi.org/10.2307/2327950

Brigham, Eugene F. \& Houston, J. F. (2009). Fundamentals of Financial Management, Concise Edition (6th). Cengage Learning

Bruhn, M., Hommes, M., Khanna, M., Singh, S., Sorokina, A., \& Wimpey, J. S. (2017). MSME finance gap: assessment of the shortfalls and opportunities in financing micro, small, and medium enterprises in emerging markets (No. 121264, pp. 1-80). The World Bank

Cassar, G., \& Holmes, S. (2003). Capital structure and financing of SMEs: Australian evidence. Accounting and Finance, 43(2), 123-147. https://doi.org/10.1111/1467-629X.t01-1-00085

Chakraborty, I. (2010). Capital structure in an emerging stock market: The case of India. Research in International Business and Finance, 24(3), 295-314. https://doi.org/10.1016/j.ribaf.2010.02.001

Cornelli, F., Portes, R., \& Schaffer, M. (1998). Financial structure of firms in the CEECs. Different Paths to a Market Economy: China and European Economies in Transition, OECD/CEPII/CEPR

Cressy, R., \& Olofsson, C. (1997). The Financial Conditions for Swedish SMEs: Survey and Research Agenda. Small Business Economics, 9(2). https://doi.org/10.1023/a:1007975924164

de Jong, A., Kabir, R., \& Nguyen, T. T. (2008). Capital structure around the world: The roles of firm- and country-specific determinants. Journal of Banking \& Finance, 32(9), 1954-1969.

https://doi.org/10.1016/j.jbankfin.2007.12.034 
Delcoure, N. (2007). The determinants of capital structure in transitional economies. International Review of Economics \& Finance, 16(3), 400-415. https://doi.org/10.1016/j.iref.2005.03.005

Delikanlı, İ., \& Kılıç, S. (2021). Factors influencing SMEs' capital structure: a comparative analysis from Turkey. Small Enterprise Research, 28(1), 57-74. https://doi.org/10.1080/13215906.2021.1889651

Demirguc-Kunt, A., \& Maksimovic, V. (1996). Stock Market Development and Financing Choices of Firms. The World Bank Economic Review, 10(2), 341-369. https://doi.org/10.1093/wber/10.2.341

Demirgüç-Kunt, A., \& Maksimovic, V. (1999). Institutions, financial markets, and firm debt maturity. Journal of Financial Economics, 54(3), 295-336. https://doi.org/10.1016/S0304-405X(99)00039-2

EL Hadj, T. (2002). Principles of Finance. Jordan: Safaa House for Publishing and Distribution

Eldomiaty, T. I. (2008). Determinants of corporate capital structure: evidence from an emerging economy. International Journal of Commerce and Management, 17(1/2), 25-43. https://doi.org/10.1108/10569210710774730

Forte, D., Barros, L. A., \& Nakamura, W. T. (2013). Determinants of the capital structure of small and medium sized Brazilian enterprises. BAR - Brazilian Administration Review, 10(3), 347-369. https://doi.org/10.1590/S1807-76922013000300007

Frank, M. Z., \& Goyal, V. K. (2009). Capital Structure Decisions: Which Factors Are Reliably Important? Financial Management, 38(1), 1-37. https://doi.org/10.1111/j.1755-053X.2009.01026.x

Ghasemi, M., \& Hisyam Ab Razak, N. (2016). The Impact of Liquidity on the Capital Structure: Evidence from Malaysia. International Journal of Economics and Finance, 8(10), 130.

https://doi.org/10.5539/ijef.v8n10p130

González, V. M., \& González, F. (2008). Influence of bank concentration and institutions on capital structure: New international evidence. Journal of Corporate Finance, 14(4), 363-375. https://doi.org/10.1016/j.jcorpfin.2008.03.010

Guler, S. (2010). An analysis on factors affecting capital structure factors of small and medium sized enterprises (SMEs) quoted on the ISE. The Journal of Faculty of Economics and Administrative Sciences, 15(3), 353-371

Habib, H., Khan, F., \& Wazir, M. (2016). Impact of debt on profitability of firms: Evidence from non-financial sector of Pakistan. City University Research Journal, 6(1)

Hacini, I., \& Dahou, K. (2013). The Evolution of the Algerian Banking System. Management Dynamics in the Knowledge Economy, 6(1), 145-166. https://doi.org/10.25019/MDKE/6.1.09

Hall, G. C., Hutchinson, P. J., \& Michaelas, N. (2004). Determinants of the Capital Structures of European SMEs. Journal of Business Finance Accounting, 31(5-6), 711-728. https://doi.org/10.1111/j.0306-686X.2004.00554.x

Hamilton, R. T., \& Fox, M. A. (1998). The financing preferences of small firm owners. International Journal of Entrepreneurial Behavior \& Research, 4(3), 239-248. https://doi.org/10.1108/13552559810235529

Handoo, A., \& Sharma, K. (2014). A study on determinants of capital structure in India. IIMB Management Review, 26(3), 170-182. https://doi.org/10.1016/j.iimb.2014.07.009

Heyman, D., Deloof, M., \& Ooghe, H. (2008). The Financial Structure of Private Held Belgian Firms. Small Business Economics, 30(3), 301-313. https://doi.org/10.1007/s11187-006-9031-0

Hongli, J., Ajorsu, E. S., \& Bakpa, E. K. (2019). The Effect of Liquidity and Financial Leverage on Firm Performance: Evidence from Listed Manufacturing Firms on The Ghana Stock Exchange. Research Journal of Finance and Accounting. https://doi.org/10.7176/RJFA/10-8-08

Jędrzejczak-Gas, J. (2018). Determinants of the capital structure of TSL sector enterprises. Management, 22(1), 122-139. https://doi.org/10.2478/manment-2018-0013

Jordan, J., Lowe, J., \& Taylor, P. (1998). Strategy and Financial Policy in UK Small Firms. Journal of Business Finance \& Accounting, 25(1\&2), 1-27. https://doi.org/10.1111/1468-5957.00176

Khanna, S., Srivastava, A., \& Medury, Y. (2015). The effect of macroeconomic variables on the capital structure decisions of indian firms: A vector error correction model/vector autoregressive approach. International Journal of Economics and Financial Issues, 5(4). https://econjournals.com/index.php/ijefi/article/view/1450

Korkmaz, T., Albayrak, A. S., \& Karataş, A. (2007). Hisse senetleri İMKB'de işlem gören KOBİ'lerin sermaye yapısının incelenmesi: 1997-2004 dönemi. İktisat İşletme ve Finans, 22(253). https://doi.org/10.3848/iif.2007.253.1548

Kuntchev, V., Ramalho, R., Rodriguez-Meza, J., \& Yang, J. S. (2013). What Have We Learned from the Enterprise Surveys Regarding Access to Credit by SMEs?, World Bank Policy Research Working Paper No. 6670. https://openknowledge.worldbank.org/handle/10986/16885

López-Iturriaga, F. J., \& Rodríguez-Sanz, J. A. (2008). Capital structure and institutional setting: a decompositional and international analysis. Applied Economics, 40(14), 1851-1864. https://doi.org/10.1080/00036840600905233

Luigi, P., \& Sorin, V. (2009). A Review of the capital structure theories. Annals of the University of Oradea: Economic Science, 3(1) 
M'ng, J. C. P., Rahman, M., \& Sannacy, S. (2017). The determinants of capital structure: Evidence from public listed companies in Malaysia, Singapore and Thailand. Cogent Economics \& Finance, 5(1). https://doi.org/10.1080/23322039.2017.1418609

Maimbo, S. M., \& Henriquez Gallegos, C. A. (2014). Interest rate caps around the world: still popular, but a blunt instrument. World Bank Policy Research, Working Paper, (7070)

Martinez, L. B., Scherger, V., \& Guercio, M. B. (2019). SMEs capital structure: trade-off or pecking order theory: a systematic review. Journal of Small Business and Enterprise Development, 26(1), $105-132$. https://doi.org/10.1108/JSBED-12-2017-0387

Mateev, M., Poutziouris, P., \& Ivanov, K. (2013). On the determinants of SME capital structure in Central and Eastern Europe: A dynamic panel analysis. Research in International Business and Finance, 27(1), $28-51$. https://doi.org/10.1016/j.ribaf.2012.05.002

Ministry of Industry and Mines (2019). SME Statistical Information Bulletin No 34. Algeria. . https://www.industrie.gov.dz/IMG/pdf/Bulletin_PME_No_34.pdf

Ministry of Industry and Mines (2019). Bulletin d'information Statistique de la PME No 35. Algeria. https://www.industrie.gov.dz/IMG/pdf/Bulletin_PME_N 35 vf.pdf

Mota, J. H. F., \& Moreira, A. C. (2017). Determinants of the capital structure of Portuguese firms with investments in Angola. South African Journal of Economic and Management Sciences, 20(1). https://doi.org/10.4102/sajems.v20i1.885

Myers, S. C. (1984). The Capital Structure Puzzle. The Journal of Finance, 39(3), 574-592. https://doi.org/10.1111/j.1540-6261.1984.tb03646.x

Myers, S. C., \& Majluf, N. S. (1984). Corporate financing and investment decisions when firms have information that investors do not have. Journal of Financial Economics, 13(2), 187-221. https://doi.org/10.1016/0304-405X(84)90023-0

Napompech, K. (2013). Determinants of Capital Structure of Small Firms in Thailand. Trends in Applied Sciences Research, 8(2), 92-104. https://doi.org/10.3923/tasr.2013.92.104

Nasimi, R. N. (2018). Determinants of Capital Structure in Pakistan. European Journal of Business and Management, 10(34), 48-60. https://iiste.org/Journals/index.php/EJBM/article/view/45649

Nguyen, T. D. K., \& Ramachandran, N. (2006). Capital Structure in Small and Medium- sized Enterprises: The Case of Vietnam. Asean Economic Bulletin, 23(2), AE23-2d. https://doi.org/10.1355/AE23-2D

Radjal, S., \& Barrak, S. F. (2017). Bank financing for small and medium enterprises As an entrance To diversify Economic. Journal of Economic and Financial Research, 4(455-484)

Rajan, R. G., \& Zingales, L. (1995). What Do We Know about Capital Structure? Some Evidence from International Data. The Journal of Finance, 50(5), 1421-1460. https://doi.org/10.1111/j.1540-6261.1995.tb05184.x

Rao, P., Kumar, S., \& Madhavan, V. (2019). A study on factors driving the capital structure decisions of small and medium enterprises (SMEs) in India. IIMB Management Review, 31(1), 37-50. https://doi.org/10.1016/j.iimb.2018.08.010

Saarani, A. N., \& Shahadan, F. (2013). The Determinant of Capital Structure of SMEs in Malaysia: Evidence from Enterprise 50 (E50) SMEs. Asian Social Science, 9(6). https://doi.org/10.5539/ass.v9n6p64

Sahin, O. (2018). Firm Specific and Macroeconomic Determinants of Capital Structure: Evidence from Fragile Five Countries. Eurasian Journal of Business and Economics, 11(22), 61-83. https://doi.org/10.17015/ejbe.2018.022.03

San Martín, P., \& Saona, P. (2017). Capital structure in the Chilean corporate sector: Revisiting the stylized facts. Research in International Business and Finance, 40, 163-174. https://doi.org/10.1016/j.ribaf.2017.01.004

Seker, M., \& Correa, P. G. (2017). Obstacles to growth of small and medium enterprises: A comparative analysis of Turkey. Bankacular Dergisi, 28(102), 14-36

Serrasqueiro, Z., Matias, F., \& Salsa, L. (2016). Determinants of capital structure: New evidence from Portuguese small firms. Dos Algarves: A Multidisciplinary e-Journal, 28, 13-28. https://doi.org/10.18089/DAMeJ.2016.28.1.2

Sogorb-Mira, F. (2005). How SME Uniqueness Affects Capital Structure: Evidence From A 1994-1998 Spanish Data Panel. Small Business Economics, 25(5), 447-457.

https://doi.org/10.1007/s11187-004-6486-8

World Bank (2019). World Bank Group Support for Small and Medium Enterprises : A Synthesis of Evaluative Findings. http://hdl.handle.net/10986/32536

World Bank (2019). Improving SMEs' access to finance and finding innovative solutions to unlock sources of capital. https://www.worldbank.org/en/topic/smefinance

World Bank (2013). Global Financial Development Report 2013: Rethinking the Role of the State in Finance. https://openknowledge.worldbank.org/handle/10986/11848 